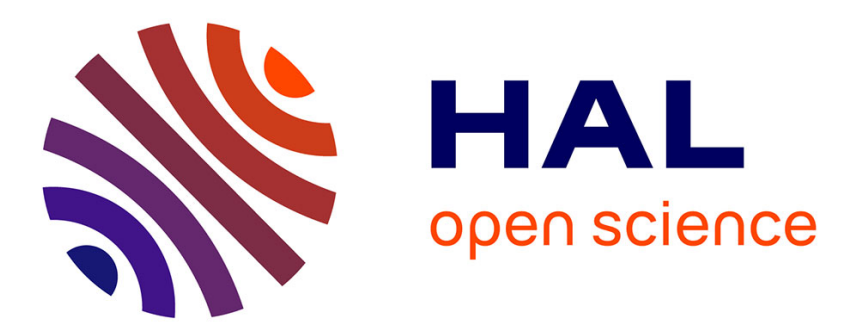

\title{
Adhesion of silver nanoparticles on the montmorillonite surface
}

J. Jonáš Tokarský, Pavla Čapková, Volker Klemm, David Rafaja, Jana

Kukutschová

\section{- To cite this version:}

J. Jonáš Tokarský, Pavla Čapková, Volker Klemm, David Rafaja, Jana Kukutschová. Adhesion of silver nanoparticles on the montmorillonite surface. Journal of Physics and Chemistry of Solids, 2010, 71 (4), pp.634. 10.1016/j.jpcs.2009.12.055 . hal-00628281

\section{HAL Id: hal-00628281 \\ https://hal.science/hal-00628281}

Submitted on 1 Oct 2011

HAL is a multi-disciplinary open access archive for the deposit and dissemination of scientific research documents, whether they are published or not. The documents may come from teaching and research institutions in France or abroad, or from public or private research centers.
L'archive ouverte pluridisciplinaire HAL, est destinée au dépôt et à la diffusion de documents scientifiques de niveau recherche, publiés ou non, émanant des établissements d'enseignement et de recherche français ou étrangers, des laboratoires publics ou privés. 


\section{Author's Accepted Manuscript}

Adhesion of silver nanoparticles on the montmorillonite surface

Joná š Tokarský, Pavla Čapková, Volker Klemm, David Rafaja, Jana Kukutschová

PII:

S0022-3697(09)00397-7

DOI: doi:10.1016/j.jpcs.2009.12.055

Reference: PCS 6043

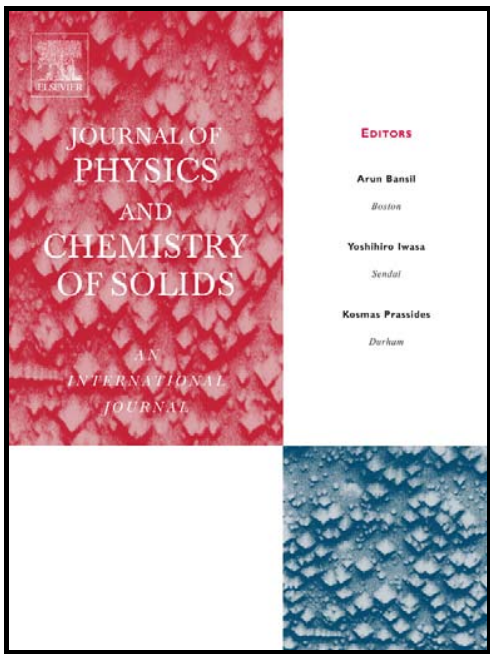

www.elsevier.com/locate/jpcs

To appear in: Journal of Physics and Chemistry of Solids

Received date: $\quad 6$ May 2009

Accepted date: $\quad 31$ May 2009

Cite this article as: Joná š Tokarský, Pavla Čapková, Volker Klemm, David Rafaja and Jana Kukutschová, Adhesion of silver nanoparticles on the montmorillonite surface, Journal of Physics and Chemistry of Solids, doi:10.1016/j.jpcs.2009.12.055

This is a PDF file of an unedited manuscript that has been accepted for publication. As a service to our customers we are providing this early version of the manuscript. The manuscript will undergo copyediting, typesetting, and review of the resulting galley proof before it is published in its final citable form. Please note that during the production process errors may be discovered which could affect the content, and all legal disclaimers that apply to the journal pertain. 


\title{
Adhesion of silver nanoparticles on the montmorillonite surface
}

\author{
Jonáš Tokarský ${ }^{*}$, Pavla Čapková1, Volker Klemm², David Rafaja ${ }^{2}$, Jana Kukutschová ${ }^{1}$ \\ ${ }^{1}$ Nanotechnology Centre, VŠB-Technical University of Ostrava, 70833 Ostrava , Czech Republic, \\ ${ }^{2}$ Institute of Material Science, TU Bergakademie Freiberg, D-09599 Freiberg, Germany
}

\begin{abstract}
Adhesion of silver nanoparticles on the montmorillonite substrate was investigated using molecular modeling (force field calculations) and experiment (infrared spectroscopy, high-resolution transmission electron microscopy). Modeling revealed the preferred orientation of silver nanoparticles on the silicate substrate and showed the strong dependence of total energy and stability of nanocomposite structure on two factors: (1) the mutual crystallographic orientation of nanoparticle and substrate structure and (2) the size and thickness of the nanoparticle. The size of silver single crystalline domains calculated by modeling was in good agreement with the experimental observations. Molecular modeling in confrontation with high-resolution transmission electron microscopy analysis showed the prediction possibility as to the nanoparticles structure and stability of nanocomposite.
\end{abstract}

Keywords: A. Nanostructures, Surfaces; B. Electron microscopy, Infrared spectroscopy; C. Crystal structure

\section{Article history}

Received: May 6, 2009

\section{Accepted: May 31, 2009}

\section{Introduction}

Nanoparticles of metals anchored on solid substrates offer a wide application field (quantum dots, solar batteries, catalysts, photocatalysts, antibacterial materials, sensors, etc.). Layer silicates, thanks to their unique properties, represent an excellent substrate for anchoring of metal nanoparticles. Present work is focused on the structure and stability of silver/montmorillonite nanocomposite (Ag/MMT). The role of particle size and surface roughness in adhesion is analyzed in [1], where the surface roughness is described using fractals and deformational forces by elastic constants for particle and substrate materials. In present work we use the atomistic model to describe the adhesion in case of nano-dimensions.

\section{Experimental}

\subsection{Preparation of Ag/MMT nanocomposite}

The natural Ca-MMT from Ivan ice, Czech Republic, was selected as starting material for experiment. The structural formula is $\left(\mathrm{Ca}_{0.24} \mathrm{~K}_{0.06} \mathrm{Na}_{0.09} \mathrm{Mg}_{0.1}\right)\left(\mathrm{Si}_{7.96} \mathrm{Al}_{0.04}\right)\left(\mathrm{Al}_{2.52} \mathrm{Fe}^{3+}{ }_{0.54} \mathrm{Mg}_{0.90}\right.$ $\left.\mathrm{Ti}_{0.04}\right) \mathrm{O}_{20}(\mathrm{OH})_{4}$. The original MMT powder sample was sieved and the fraction $<40 \mu \mathrm{m}$ was used as the host matrix for preparation of $\mathrm{Ag} / \mathrm{MMT}$ nanocomposite. The metal precursor was $\mathrm{AgNO}_{3}$ (purity $99.99 \%$, Aldrich). Clay sample was dispersed in the $0.1 \mathrm{M}$ aqueous nitrate $\left(\mathrm{AgNO}_{3}\right)$ solution and stirred for 24 hours. Solid samples were prepared by repeated centrifugation followed by washing with distilled water and drying for $24 \mathrm{~h}$ at $80^{\circ} \mathrm{C}$.

\subsection{Characterisation of Ag/MMT nanocomposite}

For characterization of the samples four experimental methods were employed: X-ray fluorescence (XRF) analysis, $\mathrm{X}$-ray powder diffraction (XRD) analysis, high-resolution transmission electron microscopy (HRTEM) analysis and Fourier transform infrared spectroscopy (FTIR) analysis.

The XRF analysis done using the energy dispersive XRF spectrometer SPECTRO X-LAB revealed the chemical composition of the Ag/MMT nanocomposite. The elemental analysis using XRF was performed on pressed pellets and confirmed the presence of Ag in the MMT particles treated by the procedure described above. Furthermore, XRF revealed that the $\mathrm{Ag}$ content in $\mathrm{Ag} / \mathrm{MMT}$ nanocomposite was $2.2 \mathrm{wt} \%$ Ag.

XRD analysis using a Bragg-Brentano diffractometer and $\mathrm{Cu}_{\mathrm{K}}$ radiation revealed that $\mathrm{Ag}$ only partially entered into the interlayer space of MMT (for more details see [1]).

HRTEM analysis was done with a $200 \mathrm{kV}$ analytical microscope JEM 2010 FEF from Jeol equipped with an ultra-high-resolution objective lens $\left(\mathrm{C}_{\mathrm{s}}=0.5 \mathrm{~mm}\right)$ and in column energy filter that was used to select only the elastic 
electrons for the image recording. The HRTEM analysis was supported by the energy-dispersive analysis of X-ray spectra (EDAX) that was done in the scanning modus transmission electron microscopy (STEM) in order to prove the local chemical composition of the nanoparticles found using HRTEM on the MMT substrate.

The mid-IR spectra were obtained on a Perkin Elmer 2000 FTIR spectrometer. For each sample, 64 scans were recorded in the 4000-400 $\mathrm{cm}^{-1}$ spectral range with a resolution of $4 \mathrm{~cm}^{-1}$ at room temperature using the $\mathrm{KBr}$ pressed disc technique $(0.8$ $\mathrm{mg}$ of sample and $290 \mathrm{mg}$ of $\mathrm{KBr}$ ).

\subsection{Strategy of the molecular modeling}

Molecular modeling in the Materials Studio modeling environment (MS) was used to analyze the interface structures and the adhesion energy of the Ag nanoparticles anchored on the silicate layer of MMT. According to the results of XRD and XRF analysis [1] our models have been built with Ag nanoparticles attached to the surface or edge of MMT.

The crystal structure of the MMT was built in the MS Crystal builder module using the structure data published by Tsipursky and Drits (1984) [2]. The lattice parameters according to Méring (1967) [3] have been used to define the planar unit cell dimensions: $a=5.208 \AA$ and $b=9.020 \AA$.

The starting model of the substrates was created by Surface builder module in MS, cleaving the 3-D periodic layer structure of MMT along the (001) and (100) planes. A series of initial models was investigated. In all of them, the $\mathrm{Ag}$ nanoparticles had prismatic shape, but various size and thickness and different crystallographic orientations on the silicate layer. The size of the nanoparticles (d) was characterized by the size of the $\mathrm{Ag}$ nanoparticles in the diagonal direction of the basal planes and the following sizes have been selected for our starting models: $1.7 \mathrm{~nm}, 2.2 \mathrm{~nm}, 3.3$ $\mathrm{nm}$ and $4.2 \mathrm{~nm}$; the heights of these prismatic nanoparticles were: 2, 4 and 6 atomic layers, respectively. The orientations of the Ag nanoparticles on the silicate surface and edge were: (100), (110) and (111) crystallographic planes of Ag structure adjacent to the silicate layer.

To create the model of a reasonable size, the structural formula of the "real" MMT, $\left(\mathrm{Ca}_{024} \mathrm{~K}_{006} \mathrm{Na}_{0.09} \mathrm{Mg}_{0.10}\right)\left(\mathrm{Al}_{252}\right.$ $\left.\mathrm{Fe}^{3+}{ }_{0.54} \mathrm{Mg}_{0.90} \mathrm{Ti}_{0.04}\right)\left(\mathrm{Si}_{7.96} \mathrm{Al}_{0.04}\right) \mathrm{O}_{20}(\mathrm{OH})_{4}$, was approximated by $\left(\mathrm{Al}_{2.56}^{0.54} \mathrm{Mg}_{0.88} \mathrm{Fe}^{3+}{ }_{0.56}\right)\left(\mathrm{Si}_{8}\right) \mathrm{O}_{20}(\mathrm{OH})_{4}$ with the total negative layer charge of -0.88 per structure formula (i.e. per 20 oxygen atoms) and the model of MMT(001) was built as a non-periodic superstructure with the formula $\left(\mathrm{Al}_{184} \mathrm{Mg}_{64} \mathrm{Fe}^{3+}{ }_{40}\right)$ $\left(\mathrm{Si}_{576}\right) \mathrm{O}_{1440}(\mathrm{OH})_{286}$ and with the total negative layer charge of $-62 \mathrm{el}$, arising from the octahedral substitutions in the silicate layer and partially from the non-stoichiometry in the coigns of the layer (see figure 1). Measure of the MMT(001) plate is 6.1 $\mathrm{nm} \times 5.1 \mathrm{~nm}$, thickness $\sim 0.9 \mathrm{~nm}$. The size and shape of the models, as well as the approximation of the structure formula, is always a compromise between a reasonable accuracy and a reasonable computing time. Our models of $\mathrm{Ag} / \mathrm{MMT}$ nanocomposites were created as non-periodic superstructures In the starting models of the MMT(001) the layer charge was compensated by the following way: (1) sixteen $\mathrm{Ca}^{2+}$ cations have been placed on the bottom side of the silicate layer compensating one half of the total layer charge (i.e. -32 el) and (2) the Ag nanoparticles located on the upper side of the silicate layer compensated the second half (i.e. -30 el) of the total layer charge.

This model has been built to describe truly the real structure of nanocomposite, where the presence of the $\mathrm{Ca}^{2+}$ cations in the interlayer space of MMT was proven by the XRD and XFR experiments in [1]. This charge compensation was set up in accordance with the nanocomposite preparation. It was assumed that at the beginning of the anchoring process an individual $\mathrm{Ag}^{+}$cation has been anchored on the negatively charged silicate layer surface as nucleus for the nanoparticle growth. Later on the charge is gradually redistributed over the growing nanoparticle.

MMT(100) plate was built as a non-periodic superstructure

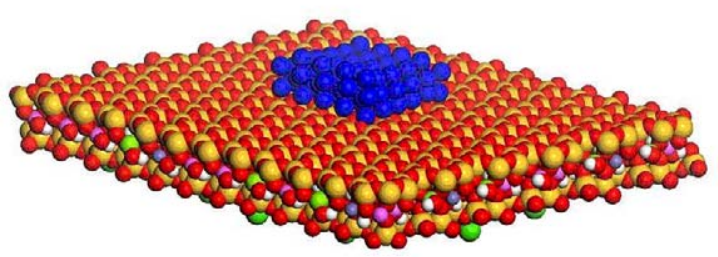

with the formula $\left(\mathrm{Al}_{394} \mathrm{Mg}_{136} \mathrm{Fe}^{3+}{ }_{86}\right)\left(\mathrm{Si}_{1231}\right)\left(\mathrm{O}_{3079}\right)(\mathrm{OH})_{602}$ and

Fig. 1. Optimized model of the four layered $\operatorname{Ag}(110)$ nanoparticle with length of the basal diagonal $2.2 \mathrm{~nm}$ anchored on the MMT oxygen faced (001) plane. The $\mathrm{Ca}^{2+}$ cations (green)

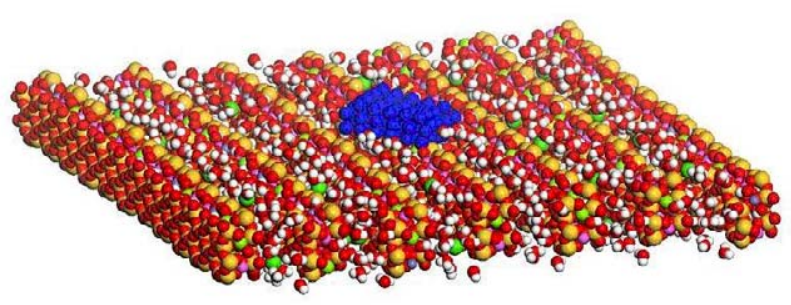

can be seen under the MMT layer.

Fig. 2. Optimized model of the four layered $\operatorname{Ag}(110)$ nanoparticle with length of the basal diagonal $2.2 \mathrm{~nm}$ anchored on the MMT (100) plane. The $\mathrm{Ca}^{2+}$ cations (green) and the water molecules can be seen in the interlayer space.

with the total negative layer charge $-124 \mathrm{el}$, arising from the octahedral substitutions in the silicate layer and from the non-stoichiometry, which occurs on the edges of the silicate layers (see figure 2). Forty seven $\mathrm{Ca}^{2+}$ cations have been placed into the interlayer space to compensate the charge of -94 el. The rest of the total negative layer charge (i.e. -30 el) was compensated by the anchored Ag nanoparticle. The interlayer distance is according to XRD data $1.5 \mathrm{~nm}$. Six hundred forty-eight molecules of water placed in the interlayer space represent the $9.2 \mathrm{wt} \%$ of the MMT(100) and this quantity is in good agreement with the experimental interlayer distance [4]. Measure of the MMT(100) plate is $9.7 \mathrm{~nm} \times 9.6$ $\mathrm{nm}$, thickness $\sim 1.25 \mathrm{~nm}$.

QEq (charge equilibration) method in MS has been used to calculate the atomic charges [5]. The interaction between the $\mathrm{Ag}$ nanoparticles and the silicate substrate was quantified using the adhesion energy:

$$
\mathrm{E}_{\text {ad }}=\left(\mathrm{E}_{\text {tot, } \mathrm{Ag}}+\mathrm{E}_{\text {tot, MMT }}\right)-\mathrm{E}_{\text {tot }}
$$

In Eq. (1), $\mathrm{E}_{\text {tot }}$ is the total energy of the nanocomposite (i.e. the Ag nanoparticle anchored on the MMT), $\mathrm{E}_{\text {tot } \mathrm{Ag}}$ is the total energy of the Ag nanoparticle and $\mathrm{E}_{\text {tot MMт }}$ is the total energy of the MMT substrate. The value of $\mathrm{E}_{\text {tot }}$ governed the stability of 
Journal of Physics and Chemistry of Solids xx (2008) xxx-xxx

the nanocomposite. Only the models with negative value of $\mathrm{E}$ can be considered as stable. The above energies are expressed in the unit [kcal] and have been calculated using the Universal force field (UFF) [6] in the Forcite module of the MS. It should be noted that our previous experience confirmed the UFF as the suitable force field for modeling of modified layer silicates $[7,8,9]$. The bonding energy term is able to describe the deformation of the Ag structure in terms of the change of the interatomic distances within the atomic planes adjacent to the silicate substrate and consequently to estimate the compatibility of both structures, the nanoparticles and the substrate.

Smart algorithm was used for the structure optimization with 50000 cycles. The convergence tresholds for the maximum energy and force changes were $1 \cdot 10^{-4} \mathrm{kcal} / \mathrm{mol}$ and $5 \cdot 10^{-3} \mathrm{kcal} / \mathrm{mol} / \bullet$, respectively. Atom based electrostatic and van der Waals summation method was used. During the structure optimization of the starting models, positions of all atoms in the substrates and all the atomic coordinates of $\mathrm{Ag}$ nanoparticles were optimized without constraints.

\section{Results}

Figure 3 (the result of FTIR) shows the comparison of IR spectra for the silicate host structure MMT and nanocomposite $\mathrm{Ag} / \mathrm{MMT}$. The positions of vibrational bands in the region $1100-400 \mathrm{~cm}^{-1}$ corresponding to $\mathrm{Si}-\mathrm{O}$ and other interlayer bonds remain unchanged, indicating the rigidity of silicate layers and non-bond interaction between silicate layers and $\mathrm{Ag}$ nanoparticles. The rigidity of the silicate layers obtained from modeling is in good agreement with the IR spectra.
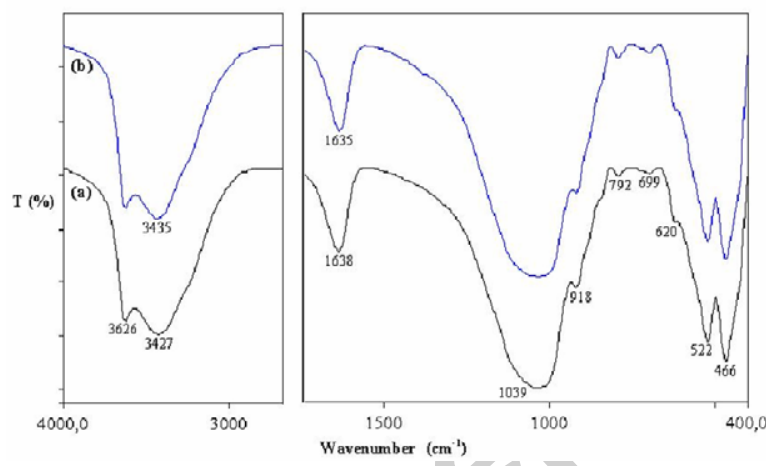

Fig. 3. Infrared spectra of the pure MMT (a) and the MMT after the treatment with $0.1 \mathrm{M}$ solution of $\mathrm{AgNO}_{3}$ (b).

The force field calculations revealed the lowest $\mathrm{E}_{\text {tot }}$ for the Ag nanoparticles that adhere with their crystallographic planes (110) on all faces of MMT layers. That means the preferred orientation of $\mathrm{Ag}$ nanoparticles is with (110) plane of $\mathrm{Ag}$ structure adherent to MMT surface. Consequently, all models for further investigations have been built using this orientation of the Ag nanoparticles.

Table 1 shows values of $\mathrm{E}$ for all sizes of $\mathrm{Ag}$ nanoparticles in $\operatorname{Ag}(110) / \mathrm{MMT}(001)$ and $\mathrm{Ag}(110) / \mathrm{MMT}(100)$, respectively. $\mathrm{E}$ is lower for the $\operatorname{Ag}(110) / M M T(001)$ than for the $\operatorname{Ag}(110) / M M T(100)$, but this fact does not mean the stronger interaction between $\mathrm{Ag}$ nanoparticles and the substrate. The values of $\mathrm{E}$ are comparable only within the models with the same type of substrate. The difference is caused by the different structure and bonding geometry in substrates $\operatorname{MMT}(001)$ and MMT(100) as one can see comparing figures 1 and 2 . Continuous surface differ from the edge because the surface contains the covalent bonds only but the partial contribution to the edge energy comes from the non-bonding interactions between the layers. We can conclude that $\mathrm{Ag}(110) / \mathrm{MMT}(001)$ is stable for larger $\mathrm{Ag}$ nanoparticles than $\mathrm{Ag}(110) / \mathrm{MMT}(100)$ (see the bottom row of the table 1) but how strong is the interaction between the nanoparticles and the substrate cannot be said until we look over the $\mathrm{E}$

In table 1 one can see that $\mathrm{E}_{\text {tot }}$ for $\mathrm{Ag}(110) / \mathrm{MMT}(001)$ nanocomposite is growing with increasing nanoparticle size and thickness, consequently we can conclude that the most favorable structure of nanocomposite contains the single crystalline Ag nanoparticles with the size $\mathrm{d}<5 \mathrm{~nm}$ for the thin two layered and with $\mathrm{d}<2.5 \mathrm{~nm}$ for the four and six layered Ag nanoparticles. The HRTEM photograph of Ag nanoparticle on MMT substrate in the figure 4 shows the $\mathrm{Ag}$ single crystalline domains within the size range similar to our findings.

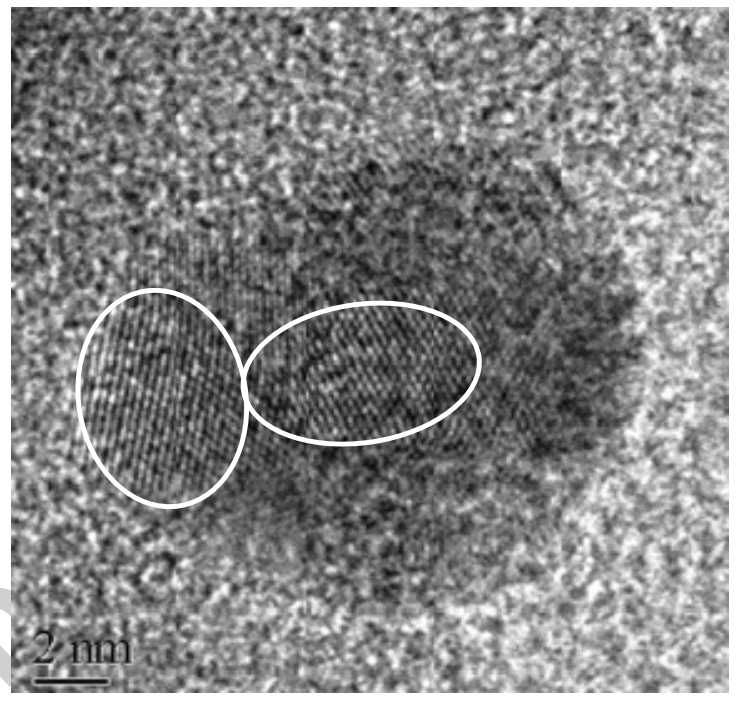

Fig. 4. HRTEM photograph of the $\mathrm{Ag}$ nanoparticles agglomerate on the MMT surface.

The $\mathrm{E}_{\text {ad }}$ for $\mathrm{Ag}(110) / \mathrm{MMT}(001)$ and $\mathrm{Ag}(110) / \mathrm{MMT}(100)$, calculated using Eq. 1 for the models with negative $\mathrm{E}_{\text {tot }}$ only, are also displayed in table 1 . The values lead to the conclusion, that $\mathrm{Ag}$ nanoparticles slightly prefer the oxygen faced MMT(001) surface for every size and thickness of Ag nanoparticle. As one can see in table 1 the $\mathrm{E}_{\text {ad }}$ steeply falls with increasing Ag nanoparticle size and thickness for both faces of MMT substrate.

In all optimized models the distortion of the $\mathrm{Ag}$ nanoparticles has been observed in dependence on the nanoparticle thickness. Two layered $\mathrm{Ag}$ nanoparticles in the whole size range and four layered Ag nanoparticles having $\mathrm{d}<$ $3 \mathrm{~nm}$ are distorted in whole volume and the distortion is accompanied by the higher $\mathrm{E}_{\text {ad }}$ (see table 1). For larger and thicker Ag nanoparticles the distortion is present only in the atomic layers adjacent to the MMT substrate.

\section{Conclusions}

Present results of modeling led to conclusions allowing deeper understanding of structure, mechanism of formation and properties of $\mathrm{Ag} / \mathrm{MMT}$ nanocomposite. Confrontation of present results of modeling with the experiment (XRD, FTIR, $\mathrm{XRF}$ and the direct visualisation of the Ag nanoparticles using HRTEM) supports results of calculations, which can be briefly summarized in following concluding notes:

- While the MMT structure remain rigid and do not undergo significant deformation, the $\mathrm{Ag}$ nanoparticle exhibits 
deformation of structure and bonding geometry, dependent on its thickness.

- $\mathrm{Ag}$ nanoparticle prefers anchoring via (110) crystallographic plane adjacent to the surface for any type of face on MMT substrate.

- $\mathrm{Ag}$ nanoparticles prefer the oxygen faced basal plane (001) of MMT for the anchoring.

- Distortion of $\mathrm{Ag}$ structure is more pronounced on the (100) MMT surface, as one can see comparing the figures 1 and 2.

- $\mathrm{E}_{\text {ad }}$ of Ag nanoparticles decreases with increasing particle size and thickness.

- Calculations also led to the conclusion, that on the basal plane (001) of MMT substrate Ag nanoparticles have no chance to grow larger than $\sim 3.3 \mathrm{~nm}$ (positive $\mathrm{E}_{\text {tot }}$ of the system) for higher thickness (thickness $\bullet 6$ atomic layers); contrary of the plane (100) of MMT, where the size of Ag nanoparticles can be larger but with the lower $\mathrm{E}$

Molecular modeling using the empirical force field was proven to be a useful tool in the investigation of the adhesion and stability of the nanoparticle/clay nanocomposites.

\section{Acknowledgement}

This work was supported by the grant of Ministry of Education in Czech Republic, grant no: MSM 6198910016 and Grant Agency of Czech Republic GA R grant no: 205/08/0869.

Table 1

$\mathrm{E}_{\text {tot }}$ and $\mathrm{E}_{\mathrm{ad}}$ of the $\mathrm{Ag} / \mathrm{MMT}$ nanocomposites. Better $\mathrm{E}_{\mathrm{ad}}$ for the $\mathrm{Ag}(110) / \mathrm{MMT}(001)$ can be seen. Value $\mathrm{d}$ is the size of $\mathrm{Ag}$ nanoparticles in the diagonal direction of basal planes.

\begin{tabular}{|c|c|c|c|c|}
\hline \multirow{2}{*}{$\begin{array}{c}\mathrm{d} \\
{[\mathrm{nm}]}\end{array}$} & \multicolumn{2}{|c|}{$\mathrm{Ag}(110) / \mathrm{MMT}(001)$} & $\mathrm{Ag}(110) / \mathrm{MMT}(100)$ \\
\cline { 2 - 5 } & $\begin{array}{c}\mathrm{E}_{\mathrm{tot}} \\
{[\mathrm{kcal}]}\end{array}$ & $\begin{array}{c}\mathrm{E}_{\text {ad }} \\
{[\mathrm{kcal}]}\end{array}$ & $\begin{array}{c}\mathrm{E}_{\text {tot }} \\
{[\mathrm{kca}]}\end{array}$ & $\begin{array}{c}\mathrm{E}_{\text {ad }} \\
{[\mathrm{kcal}]}\end{array}$ \\
\cline { 2 - 5 } & \multicolumn{2}{|c|}{2 layers } & \multicolumn{2}{|c|}{2 layers } \\
\hline 1.7 & -426271 & 534 & -870472 & 494 \\
\hline 2.2 & -417557 & 294 & -859777 & 222 \\
\hline 3.3 & -398832 & 121 & -842638 & 94 \\
\hline 4.2 & -378681 & 68 & -821331 & 49 \\
\hline & \multicolumn{2}{|c|}{4 layers } & \multicolumn{2}{|c|}{4 layers } \\
\hline 1.7 & -377098 & 207 & -821909 & 192 \\
\hline 2.2 & -337667 & 120 & -781959 & 104 \\
\hline 3.3 & -196042 & 43 & -663739 & 30 \\
\hline 4.2 & -87895 & 29 & -530526 & 19 \\
\hline \multicolumn{2}{|c|}{6 layers } & \multicolumn{2}{|c|}{6 layers } \\
\hline 1.7 & -325200 & 117 & -767898 & 83 \\
\hline 2.2 & -251966 & 69 & -697062 & 64 \\
\hline 3.3 & -21410 & 28 & -463683 & 17 \\
\hline 4.2 & 229297 & - & -212685 & 10 \\
\hline
\end{tabular}

\section{References}

[1] M. Valášková, G. Simha Martynková, J. Lešková, P. apková, V. Klemm, D. Rafaja, Journal of Nanoscience and Nanotechnology 8 (2008), 3050-3058.

[2] S.I. Tsipurski, V.A. Drits, Clay Minerals 19 (1984), 177-193.

[3] J. Mering, A. Oberlin, Clays Clay Miner 27 (1967), 3-25.

[4] K. Jasmund, G. Lagaly, Tonminerale und Tone: Struktur, Eigenschaften, Anwendungen und Einsatz in Industrie und Umwelt. Steinkopff, Darmstadt, 1993, p. 130-131.

[5] A.K. Rappe, W.A. Goddard, J. Phys. Chem. 95 (1991), $3358-3363$.

[6] A.K. Rappe, C.J. Casewit, K.S. Colwell, W.A. Goddard, W.M. Skiff, J. Am. Chem. Soc. 114 (1992), 10024-10035.

[7] P. apková, M. Pospíšil, M. Valášková, D. M inská, M. Trchová, Z. Sedláková, Z. Weiss, J. Colloid Interface Sci. 300 (2006), 264-269.

[8] M. Pospíšil, A. Kalendová, P. apková, J. Šimoník, M. Valášková, J. Colloid Interface Sci. 277 (2004), 154-161.

[9] L. Kulhánková, P. apková, V. Ramirez de Valle, J. Poyato, J.L. Perez-Rodriguez, A. Lerf, J. Mol. Model. 14 (2008), 1183-1189. 